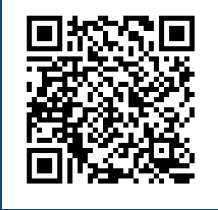

Keywords:

Altantic forest

Cabralea canjerana

Forest restoration

Forest gaps

Plant ecophysiology

Historic:

Received 18/1 1/2018 Accepted 08/03/2019

Correspondence: corinagraciano@agro.unlp.edu.ar
Ana P. Moretti ${ }^{1 a, 2}$, Flavia Y. Olguin ${ }^{1 b, 2}$, Martín A. Pinazo ${ }^{3 a}$, Corina Graciano $1,2,4 a+$

\section{WATER AND LIGHT STRESSES DRIVE ACCLIMATION DURING THE ESTABLISHMENT OF A TIMBER TREE UNDER DIFFERENT INTENSITIES OF RAINFOREST CANOPY COVERAGE}

MORETTI, A. P.; OLGUIN, F. Y.; PINAZO, M. A.; GRACIANO, C. Water and light stresses drive acclimation during the establishment of a timber tree under different intensities of rainforest canopy coverage. CERNE, v. 25, n. I, p. 93-104, 2019.

\section{HIGHLIGHTS}

In a shade-tolerant species under full sun, growth was limited by water deficit.

Stress by excess of light was irrelevant but low light availability limited growth.

Acclimation strategies enables plants to establish in different forest microenvironments.

The capacity of the species to avoid severe stress make it proper to restoration plans.

\section{ABSTRACT}

The loss of structure, diversity and functions in the rainforests makes it necessary to develop active strategies to restore their economic and ecological values. Planting selected species can help to catalyze ecosystem restoration. The capacity of the plants to survive and grow in the rainforests, where the canopy coverage changes stochastically, is associated with the intrinsic requirements of the species and their phenotypic plasticity. We used a mid-succession subtropical tree (Cabralea canjerana) to describe the morphological and physiological changes in plant acclimation to full sun and under a closed canopy, and to evaluate the establishment of this species under different intensity of canopy coverage in the rainforest. Traits related with light and water use were analyzed to identify if plants were suffering light or water stresses. Plants changed several morphological and physiological traits related with water and light use, to acclimate to different coverings. Water deficit stress drove acclimation under full sun while the stress by excess of light was irrelevant. However low light availability limited growth under the closed forest canopy. Consistently, the better growth and physiological performance were observed in the center of the gaps. The capacity of this species to acclimate both to high and low coverage and to survive makes it appropriate for enrichment programs in tropical and subtropical rainforests. The evaluation of morpho-physiological traits, even in a pot experiment, is useful to know the capacity of the species to survive and grow in different environments in the rainforest. 


\section{INTRODUCTION}

The area covered with rainforests has diminished all around the world because native forests have been replaced to produce food or to plant fast growing trees. Moreover, the selective extraction of valuable species reduces the biodiversity and the economic value of the remnant rainforest. In this context, ecological restoration is useful to recover the structure of the ecosystem, to increase the economic value of the forest as well as to meet conservation purposes. To re-establish the functions of an ecosystem, planting is an option that enables to speed up site restoration and to introduce seedlings of valuable species even far from their parents (Montagnini and Jordan 2005).

The capacity of a plant to survive and grow with different availability of canopy coverage is associated with the intrinsic requirements of the species (i.e. shade tolerant or light demanding). However, changes in light incidence in the understory are associated with changes in soil water availability and atmospheric vapor deficit (Gálhidy et al. 2006). Therefore, some changes in the hydraulic architecture of plants should occur in the acclimation to full sunlight or to the shade below a dense canopy. To manage adequately the enrichment of degraded rainforests, it is necessary to know the capacity of the species to acclimate to different environments. It is important to identify if plants under full sunlight can adequate their physiology to avoid severe light and water stresses. On the other hand, it is necessary to evaluate if plants under a closed canopy are stressed by the lack of enough radiation. Species with higher phenotypic plasticity will be easier to manage in complex ecosystems like the rainforests, characterized by dynamic changes in canopy coverage (Felton et al. 2006), because plasticity enables plants to catch or retain resources that are available in low levels and to avoid damages produced by an excess of resources. For example, if seedlings are planted below a close canopy, acclimation to shade is necessary. However, sudden canopy openness can occur because of a big tree fall. In that moment, shade acclimated plants will be exposed to higher radiation, evaporative demand and temperature. Therefore, the ability of the plants to modify its morphology and physiology is relevant to ensure its survivor and growth in a changing environment as a rainforest (Benito Garzón et al. 20I I).

In any environment, if the resources needed for plant growth are not available in an adequate range, plants suffer stress. The level of the stress is related with the amount of resources available and the duration of the excess or limitation. Some physiological responses can occur in minutes to hours, like stomatal closure or chlorophyll degradation. If the stress is relieved with these responses, the stress is mild. If the first responses are not enough to release the stress, some modifications can occur in days or months, namely acclimation, like changes in total leaf area, leaf, root and stem anatomy and physiology or dry mass partitioning. Those changes can be enough to release stress, therefore there is no reduction in total plant growth. In this situation, the stress is moderate. However, the stress is severe if the lack or excess of resources is far from the optimal range; in that situation the acclimations are not enough to prevent a reduction in growth (i.e. whole-plant mass accumulation, height) (Lambers et al. 1998; Larcher 2003). Therefore, physiological and morphological acclimations as well as reduction of growth are signals of stress (Niinemets 2010).

We used as a model a timber tree species from the Atlantic Forest, Cabralea canjerana (Vell.) Mart, widely distributed in the tropical and subtropical rainforests in America (Carpenedo Aimi et al. 2016). It has valuable wood, high growth rates, and its natural regeneration is abundant in different environments within the rainforest. C.canjerana is considered a mid-succession species, that tolerates shade during the juvenile phase, and reaches the upper canopy when adult. We analyze the response of C.canjerana to abiotic stresses in different positions in gaps, and how learning the biology of the species can help to design forest restoration practices. In this paper, reversible responses in the short term are considered mild stress, acclimations without reduction of growth are considered moderate stress and reduction in growth is considered severe stress. The aims were I) to describe the morphological and physiological changes during the early establishment in the acclimation to contrasting canopy coverage (full sun and under a closed canopy), and 2) to evaluate if this species suffers light or water stress under different intensity of canopy coverage in the rainforest. The hypothesis is that C.canjerana can acclimate to sun and canopy coverage, but plants suffer stress by excess of light and water deficit in open areas and stress by deficit of light under the dense canopy.

\section{MATERIAL AND METHODS}

\section{Study area and species selected}

The experiments were carried out in a subtropical Atlantic forest (Campo Anexo Manuel Belgrano, INTA EEA Montecarlo, San Antonio, Misiones, Argentina) 
$\left(26^{\circ} 02^{\prime} 56.9 I^{\prime \prime}\right.$ 'S; $53^{\circ} 46^{\prime} 14.15^{\prime \prime}$ 'W. 552 masl), that belongs to the Alto Paraná region. The average annual temperature is $21^{\circ} \mathrm{C}$, and the mean annual rainfall is about $2000 \mathrm{~mm}$, distributed equally along the year. The predominant soils are Ultisols. The species Cabralea canjerana (Vell.) Mart. (Meliaceae) was selected because it naturally grows in different environments within the forest, from Costa Rica to northern of Argentina. C.canjerana is a mid-successional species and young plants are considered shade tolerant (Cargnelutti Filho et al. 20I2). When adult, this species can reach $30 \mathrm{~m}$ high and $1.5 \mathrm{~m}$ of stem diameter.

Two experiments were performed. The pot experiment was to compare plants acclimated to full sunlight (sun plants) with plants acclimated to a closed rainforest canopy (shade plants). The gap experiment was installed in natural gaps in the rainforest to compare plant growth and acclimation to different natural degrees of coverage. Seeds germinated in trays and were transplanted to $350 \mathrm{~cm}^{3}$ transplant trays, filled with 50:50 mix of pine bark compost and forest soil. Plants grew in a greenhouse covered with a green shade cloth until the beginning of the experiments.

The pot experiment enabled to measure many physiological and morphological traits and destructive sampling that can describe acclimation capacity and stress tolerance, in a relatively easy way. The gap experiment was useful to demonstrate whether the traits measured in the pot experiment are useful to predict the stress response, in acclimation and growth, of the plants in different sites in the rainforest. Although natural regeneration is abundant, planting was necessary to choose microenvironments with different levels of coverage and to ensure that all the plants to be measured had the same age.

Growing conditions of sun and shade plants (pot experiment)

In spring 2012 (October), 8-months old C.canjerana plants were planted in 7-litres pots filled with soil and compost mixture. Mean plant height was 15 $\mathrm{cm}$ and standard deviation was $2 \mathrm{~cm}$. Plants were placed in two contrasting environments given by the presence or not of canopy coverage: 34 plants were placed in an open area exposed to full sunlight (sun plants) and 34 plants were placed under the closed rainforest canopy (shade plants). Plants were watered daily, twice a day in hot days in the sun position. After summer (May 2013), morphological and physiological traits were measured to characterize the acclimation of $C$.canjerana plants to each environment. These contrasting covers imply not only differences in incident radiation but also several changes in ambient conditions. Soil and air temperature and relative humidity were measured with a thermohygrometers (TFA 30.5000.02, Wertheim, Germany) in all the plants. Simultaneously, photon flux density of photosynthetic active radiation (PAR) and red:far red ratio were measured with a Red Tide USB 650 espectroradiometer (Ocean Optics, Dunedin, Florida, USA).

\section{Growth and dry mass partitioning}

Total plant height was measured with metal measuring tape; collar diameter, with precision calipers $(0.01 \mathrm{~mm})$ and number of leaves were counted in all plants $(n=34)$. Then, leaf area $\left(\mathrm{cm}^{2}\right)$ and specific leaf area (SLA) $\left(\mathrm{cm}^{2} \cdot \mathrm{g}^{-1}\right)$ were measured in six plants randomly chosen from each treatment. Leaf area was measured on digital photographs of all the leaves with ImageTool version 1.28 CMEIAS upgrade program. Finally plants were dried at $60^{\circ} \mathrm{C}$ to constant weight, to determine whole-plant mass (g) and dry mass partitioning (stem, leaves, fine roots and taproot). Leaf mass ratio is the rate between leaf dry mass and total dry mass of each plant, and root mass ratio is the rate between rott dry mass with total dry mass.

Stomatal density (SD) and index (SI), stomatal conductance and leaf water potential

Stomatal density, epidermal cells number by $\mathrm{mm}^{2}$ and stomatal index were measured in 2 leaf discs of 9 plants per treatment taken from upper fully expanded leaves grown during the acclimation $(n=18)$. Leaf discs (diameter $=5 \mathrm{~mm}$ ) were cut and immediately stored in fixative (50 ethanol: 10 formaldehyde: 5 acetic acid: 35 deionized water). Discs were diaphanized and stained with safranin 1\%. Photographs were taken with a microscope (Carl Zeiss Photomicroscope II, Oberkochen, Germany). Finally stomatal density and number of epidermal cells were counted. Stomatal index was calculated as the quotient between stomatal density and epidermal cell number (Haworth et al. 20II).

In order to evaluate the water status of the plants throughout the day, stomatal conductance $(\mathrm{gs})\left(\mathrm{mmol} \mathrm{H}_{2} \mathrm{O}\right.$ $\left.\mathrm{m}^{-2} \cdot \mathrm{s}^{-1}\right)$ was measured with a steady state leaf porometer Decagon SCI (Decagon Devices, Pullman, Washington, USA) and leaf water potential ( $\Psi$ ) (Mpa) was measured using a Schölander type pressure chamber (BioControl, Buenos Aires, Argentina). For each treatment, 6 plants were randomly selected each time to measure gs, and 3 plants to measure $\Psi$, at 9:00. 12:00. 14:00 and 17:00 h, 
repeated 3 days. Different plants were chosen each time, in order to avoid measures repeated in time.

Hydraulic conductances and conductivities of leaves, stems and roots

Hydraulic conductances were measured with the pressure-drop hydraulic flow meter (Melcher et al. 20I2). Perfusion was made with de-gassed filtrated distilled water, using $4.5 \mathrm{kPa}$ pressure. Shoot (stem with leaves) was cut at collar under water and immediately connected to the fixing tube. The hydraulic conductance was measured when water flow was stable. Then, the complete root system was connected to the flow meter to measure Kroot. For that, the final portion of the main root was cut to perfuse the water from root tip to plant collar. The root was kept under water when measuring.

The hydraulic conductance of whole plant $\left(\mathrm{K}_{\text {plant }}\right)$ was calculated (Rodríguez-Gamir et al. 2016): $\mathrm{K}_{\text {plant }}=$ $\mathrm{I} /\left(\mathrm{I} / \mathrm{K}_{\text {root }}+\mathrm{I} / \mathrm{K}_{\text {shoot }}\right)$. As there were differences in plant size in sun and shade plants, $\mathrm{K}_{\text {root }}$ and $\mathrm{K}_{\text {shoot }}$ were standardized by the leaf area and root dry mass, to estimate the specific conductance of root and shoot. Complementary, Huber value (Carter and White 2009) was calculated as the ratio between the stem xylem area and total leaf area of each of the six plants per treatment used to measure hydraulic conductance .

Chlorophyll concentrations, net photosynthetic rate, ETR and Fv/Fm

Chlorophylls were extracted from one leaf disc (5 mm diameter) in I $\mathrm{ml}$ of N,N-Dimethylformamide during $48 \mathrm{~h}$ in dark, in 10 samples per treatment taken from upper fully expanded leaves, one sample per plant. Chlorophyll concentrations were measured with a spectrophotometer at 647 and $664.5 \mathrm{~nm}$ (Inskeep and Bloom 1985)N-dimethylformamide (DMF. Total chlorophyll concentration $\left(\mathrm{mg} \cdot \mathrm{cm}^{-2}\right.$ and $\mathrm{mg} \cdot \mathrm{g}^{-1}$ dry matter) and chlorophylls $\mathrm{a} / \mathrm{b}$ ratio were calculated.

To evaluate the photosynthetic capacity of the plants acclimatized to each environment, 6 plants were randomly selected for each treatment to measure net photosynthetic rate $\left(\mu \mathrm{mol} \mathrm{CO} \mathrm{m}^{-2} \cdot \mathrm{s}^{-1}\right)$ with an Infra Red Gas Analyzer (IRGA Ciras 2, PP System, Amesbury, USA). Chamber condition settings were: 360 ppm of ambient $\mathrm{CO}_{2}$ and $25^{\circ} \mathrm{C}$. Photosynthetic photon flux density was incremented from 0 to $2000 \mu \mathrm{mol} \cdot \mathrm{m}^{-2} \cdot \mathrm{s}^{-1}$. Apparent mitochondrial respiration $\left(R_{L A}\right)$, light compensation point and net photosynthetic rate at light saturation (Asat ${ }_{\mathrm{LA}}$ ) were calculated on leaf area basis. Additionally, net photosynthetic and respiration rates (Asat ${ }_{\mathrm{LDM}}$ and $\mathrm{R}_{\mathrm{LDM}}$, respectively) were expressed in leaf dry mass basis $\left(\mu \mathrm{mol} \mathrm{CO} \mathrm{g}^{-1} \mathrm{~s}^{-1}\right)$ taking into account specific leaf area (SLA). Six curves per treatment were adjusted and the parameters were compared by ANOVA.

Electron transport rate (ETR) and intrinsic photosystem II quantum yield ( $\phi$ PSII) were measured in naturally lit plants with a pulse method fluorescence meter (FMS2, Hansatech, Norfolk, UK). During 3 sunny days, 10 plants for each treatment were randomly selected at 9:00. 12:00. 14:00 and 17:00 h to analyze daily pattern. Maximum quantum yield of photosystem II $(\mathrm{Fv} / \mathrm{Fm})$ was measured in one leaf per plant to estimate damage in photosynthetic system. At sunset, 10 plants for each treatment were randomly selected to measure $\mathrm{Fv} / \mathrm{Fm}$ in one leaf per plant with the saturation pulse method (FMS2, Hansatech, Norfolk, UK) after $30 \mathrm{~min}$ acclimation to dark.

\section{Plants growing in forest gaps (gap experiment)}

On September 2014 (spring), 162 C.canjerana were planted in six different positions (north, south, east, west and center of the gap and under the dense rainforest canopy) within 3 natural gaps in the rainforests of 68,119 and $172 \mathrm{~m}^{2}$ of extended area. The different positions in each gap imply that plants were exposed to a gradient of canopy coverage, from more open areas in the center of the gaps to closed areas below the canopy. Nine plants were planted in each position in each gap. Plant height was $14 \pm 4 \mathrm{~cm}$ and collar diameter was $5 \pm 1$ $\mathrm{mm}$ (mean \pm SD). Six months later, on March 2015 (after summer) morphological and physiological traits were measured as well as some environmental conditions. To describe canopy cover condition, photosynthetic photon flux density was measured at midday just above each plant with a ceptometer (Cavadevices, Buenos Aires, Argentina) $(n=147)$. Complementary, transmitted light (\%) was estimated with hemispherical photographs taken in each position in each gap $(n=18)$. Pictures were taken with a fisheye lens put Im height, before sun rise to avoid sunfleck distortions in the images. Photographs were taken with a $180^{\circ}$ fish-eye Nikon FC-E9 lens with a system self-leveling SML-6, Delta T Devices system, adapted to the Nikon Coolpix 8400 digital camera with a Nikon UR-EI 6 adaptor and analyzed with GLA (Gap Light Analyzer) software (Frazer et al. 1999)size, and location of gaps in a forest canopy have a direct influence on the availability and distribution of understory light. The quantity and spectral quality of this incident solar energy, in turn, plays a significant role in determining the abundance and diversity of understory plants, the 
growth and mortality of seedlings, and the development, structure, and species composition of the canopy trees (Canham et al. 1994, Gray and Spies 1996, Wright et al. 1998, Nicotra et al. 1999. This software estimates transmitted light along the year, considering the canopy and the geographic coordinates. Air temperature, soil temperature and air relative humidity were measured with thermohygrometers (TFA 30.5000.02, Wertheim, Germany) at midday in three days in three plants per position per gap to describe plant environment $(n=147)$. Soil water content $(0-20 \mathrm{~cm}$ soil depth) was measured gravimetrically, in one sample per position per gap $(n=18)$, by measuring initial weight, dry weight and saturated weight of each sample. Morphological traits measured in all plants alive $(n=147)$ were: total plant height, collar diameter, leaflet dry mass $(g)$ and leaflet area $\left(\mathrm{cm}^{2}\right)$ to calculate specific leaf area (SLA). Stomatal conductance at midday and photosystem II electron transport rate (ETR) at midday were measured in three plants per position per gap, in one leaf per plant, in three sunny days. In the case of plants measured more than one day, data were averaged to do the correlation with PAR. Chlorophyll concentration and maximum photosystem II quantum yield (Fv/Fm) were measured in three plants per position per gap $(n=54)$. All traits were measured with the same methodology and equipment described in the pot experiment.

\section{Statistical analysis}

Data were analyzed with InfoStat (Di Rienzo et al. 20I5). The morphological and physiological variables were analyzed using ANOVA with one factor and two levels (sun and canopy). In the case of the variables measured along the day, two factors were considered: condition (sun or canopy) and time (4 levels) and their interaction. If ANOVA was significant $(p<0.05)$, the post hoc analysis was done with Tukey test with $p<0.05$. In the gap experiment, descriptive statistics and correlation between PAR and the variables were done taking all the plants together. As a complementary approach, plants were divided in three ranges according with the percentage of transmitted light in the gap and position, and an ANOVA was performed. In the case variables did not fit ANOVA assumptions, non-parametric Kruskal Wallis analysis was done. In all the cases that not all the plants were measured, we picked each time haphazardly the plants to be measured to avoid autocorrelation.

\section{RESULTS}

\section{Environmental conditions}

In the pot experiment, during the measurements at midday, mean soil temperature was $19.6 \pm 0.8^{\circ} \mathrm{C}$ on sun plants and $16.9 \pm 0.2^{\circ} \mathrm{C}$ on shade plants, mean air temperature was $26.9 \pm 0.6^{\circ} \mathrm{C}$ under the sun and $27.6 \pm 0.7^{\circ} \mathrm{C}$ under the canopy, and mean air relative humidity $(H R)$ was $34.1 \pm 2.3 \%$ and $39.3 \pm 1.6 \%$ on sun and shade, respectively. Photosynthetic photon flux density (PAR) varied between 66 and $1799 \mu \mathrm{mol}$ photons $\mathrm{m}^{-2} \cdot \mathrm{s}^{-1}$ along the day in sun plants, while variation was between 19 and $213 \mu \mathrm{mol}$ photons $\mathrm{m}^{-2} \cdot \mathrm{s}^{-1}$ in shade plants. At midday, PAR was $1793 \pm 59$ under the sun and $88 \pm 7$ under the canopy. Radiation under the canopy was enriched with far red $(r: f r=0.99 \pm 0.02$ under the sun and $0.5 \mathrm{I} \pm 0.03$ under the canopy).

Plant morphology, size and dry mass partitioning in sun and shade plants

Shade plants were taller and had smaller collar diameter than sun plants (Table I). Stem and leaf dry mass were similar in both treatments. However, fine and coarse root dry weights were higher in sun than in shade plants. Therefore whole-plant dry weight was higher in sun than in shade plants (Table I). Shade plants invest more dry mass in above ground organs, as reflected in their higher shoot:root and leaf mass ratio and lower root mass ratio respect to sun plants. Although whole-plant leaf dry mass was similar in both treatments, specific leaf area (SLA) was higher in canopy than in sun plants. Shade plants developed more leaves and wider total leaf area. Stomatal number and density of epidermal cells of sun plants were higher than those of shade plants. Stomatal index (SI) in sun plants was double than in shade plants (Table I).

Hydraulic architecture traits in sun and shade plants

Whole plant hydraulic conductance and the hydraulic conductance of shoot and root were similar in sun and shade plants (Table 2), in spite of their different architecture and dry mass partitioning (Tablel). Huber value (i.e. the investment in xylem per unit leaf area) was 6-folds higher in sun plants than in shade plants. Therefore, plant hydraulic architecture is different if the canopy coverage is present or not.

In sun plants, stomatal conductance (gs) was steady along the day, with a slow decrease at midday, the moment with higher evaporative demand (Figure I). Consistently, leaf water potential dropped at midday. On contrary, in shade plants the highest stomatal 
conductance was at midday and no decrease in leaf water potential was registered (Figure I).

Traits related with light use in sun and shade plants

Sun plants had lower chlorophyll concentration than shade plants expressed in area and dry mass basis (Table 2). Chlorophyll a/b ratio was lower in shade plants than in sun plants. Maximum net photosynthetic rate at light saturation on leaf area basis (Asat ${ }_{L A}$ ), dark respiration rate $\left(R_{L A}\right)$ and light compensation point were similar in both treatments. Maximum net photosynthetic rate at saturation light and respiration rate on leaf dry mass basis (Asat ${ }_{L D M}$ and $R_{L D M}$, respectively) were higher in shade than in sun plants. The differences between the photosynthetic and respiration rate expressed on leaf area respect to those expressed on leaf dry mass basis are related with differences in SLA between treatments (Table I). Maximum photosystem II quantic yield (Fv/Fm) was lower in sun than in shade plants. The photosystem

TABLE I Morphological traits of C.canjerana plants growing in an open area (sun) or under the dense rainforest canopy (shade) after 6-month acclimation in the pot experiment (mean \pm standard error), replications per treatment $(n)$, and $F$ and $p$-value of the ANOVA. Different letters show significant differences between means of shade and sun $(p<0.05)$.

\begin{tabular}{|c|c|c|c|c|c|}
\hline & sun & shade & $\mathrm{n}$ & $\mathrm{F}$ & $p$ \\
\hline $\begin{array}{l}\text { Height } \\
(\mathrm{cm})\end{array}$ & $2 \mathrm{I} . \mathrm{I} \pm 1.4(\mathrm{a})$ & $29.3 \pm I(b)$ & 34 & 23.7 & $<0$ \\
\hline $\begin{array}{l}\text { Collar diameter } \\
\qquad(\mathrm{mm})\end{array}$ & $10.5 \pm 0.4(b)$ & $7.1 \pm 0.3$ (a) & 34 & 52.0 & $<0.0$ \\
\hline Number of & $5 \pm 1(a)$ & $\mathrm{II} \pm \mathrm{I}(\mathrm{b})$ & 34 & 75.1 & $<0.0$ \\
\hline $\begin{array}{l}\text { Total leaf area } \\
\qquad\left(\mathrm{cm}^{2}\right)\end{array}$ & $283 \pm 54(a)$ & $964 \pm 83(b)$ & 6 & 47.3 & $<0$ \\
\hline $\begin{array}{l}\text { Specific leaf area } \\
\left(\mathrm{cm}^{2} \cdot \mathrm{g}^{-1}\right)\end{array}$ & $118 \pm 9(a)$ & $245 \pm 10(b)$ & 6 & 87.3 & $<0$ \\
\hline $\begin{array}{l}\text { Stomatal density } \\
\qquad\left(\mathrm{n}^{\circ} \cdot \mathrm{mm}^{-2}\right)\end{array}$ & $109 \pm 8(b)$ & $54 \pm 2(a)$ & 18 & 39.2 & $<0$ \\
\hline $\begin{array}{l}\text { Density of epidermal cells } \\
\qquad\left(\mathrm{n}^{\circ} \cdot \mathrm{mm}^{-2}\right)\end{array}$ & $1315 \pm 36(b)$ & $1194 \pm 45(a)$ & 18 & 4.3 & 0.04 \\
\hline $\begin{array}{c}\text { Stomatal Index } \\
\left(n^{\circ} \text { stomata } n^{\circ} \text { cells }{ }^{-1}\right)\end{array}$ & $8.6 \pm 0.7(b)$ & $5.3 \pm 0.3(a)$ & 18 & 19.6 & $<0$ \\
\hline $\begin{array}{c}\text { Stem dry mass } \\
\text { (g) }\end{array}$ & $3.7 \pm 0.62(a)$ & $2.4 \pm 0.4(a)$ & 6 & 3.2 & 0.10 \\
\hline $\begin{array}{l}\text { Leaf dry mass } \\
\qquad(\mathrm{g})\end{array}$ & $2.6 \pm 0.6(a)$ & $4.0 \pm 0.4(a)$ & 6 & 3.7 & 0.08 \\
\hline $\begin{array}{l}\text { Fine root dry mass } \\
\qquad(\mathrm{g})\end{array}$ & $3.5 \pm 0.5(b)$ & $\mathrm{I} .2 \pm 0.1$ (a) & 6 & 21.0 & $<0$ \\
\hline $\begin{array}{c}\text { Tap root dry mass } \\
(\mathrm{g})\end{array}$ & $7.7 \pm 1.6(b)$ & $2.1 \pm 0.4(a)$ & 6 & 11.9 & $<0$ \\
\hline $\begin{array}{l}\text { Whole-plant dry mass } \\
\text { (g) }\end{array}$ & $17.4 \pm 3.1$ (b) & $9.6 \pm 1.2(a)$ & 6 & 5.5 & 0.04 \\
\hline $\begin{array}{l}\text { Shoot:root dry mass ratio } \\
\qquad\left(g \cdot g^{-1}\right)\end{array}$ & $0.6 \pm 0.7(a)$ & $2.0 \pm 0.1(b)$ & 6 & 72.8 & $<0$ \\
\hline $\begin{array}{l}\text { Leaf mass ratio } \\
\qquad\left(g \cdot g^{-1}\right)\end{array}$ & $0.14 \pm 0.01(a)$ & $\begin{array}{l}0.42 \pm \\
0.03(b)\end{array}$ & 6 & 81.9 & $<0$ \\
\hline $\begin{array}{l}\text { Root mass ratio } \\
\left(\mathrm{g} \cdot \mathrm{g}^{-1}\right)\end{array}$ & $\begin{array}{c}0.64 \pm 0.03 \\
\text { (b) }\end{array}$ & $\begin{array}{c}0.34 \pm 0.02 \\
\text { (a) }\end{array}$ & 6 & 98.8 & $<0$ \\
\hline
\end{tabular}

II electron transport rate (ETR) was higher in sun than in shade plants from the morning to past midday, but was similar in both treatments late in the afternoon (Figure 2). The quantum yield of photosystem II ( $\varphi$ PSII) was higher in shade than in sun plants along the day. Therefore, shade plants used near $70 \%$ of the incident radiation while sun plants used between 10-30\% of the radiation. However, as PAR in the sun position was much higher than under the canopy, ETR was higher in sun plants (Figure 2).

Morphological and physiological responses to different canopy coverage in gaps

Six months after planting, plant height varied between 4 to $58 \mathrm{~cm}$, and collar diameter ranged between 2.5 to $9.5 \mathrm{~mm}$ (Table 3). Some plants were shorter than when they were planted because the shoot was damaged partially or totally. Partially damaged plants $(n=12)$ were included in the analysis, but plants without shoot $(n=15)$

TABLE 2 Physiological traits of C.canjerana plants growing in an open area with full sun (sun) and under the dense rainforest canopy (shade) during the summer in the pot experiment (mean \pm standard error), number of replications per treatment, and $F$ and $p$-value of the ANOVA. Different letters show significant differences between means of shade and sun $(p<0.05)$.

\begin{tabular}{|c|c|c|c|c|c|}
\hline & sun & shade & $\mathrm{n}$ & $\mathrm{F}$ & $p$ \\
\hline \multicolumn{6}{|l|}{ Hydraulic traits } \\
\hline Kplant & $27+0.4$ & $1.7+0.5$ (a) & 6 & 28 & 0.12 \\
\hline $\begin{array}{c}\left(\mathrm{g} \cdot \mathrm{MPa}^{-1} \cdot \mathrm{h}^{-1}\right) \\
\text { Kshoot }\end{array}$ & $2.1 \pm 0.4$ & $1.1-0.0$ (a) & & & \\
\hline$\left(\mathrm{g} \cdot \mathrm{MPa}^{-1} \cdot \mathrm{h}^{-1}\right)$ & $2.9 \pm 0.5(a)$ & $1.7 \pm 0.4(\mathrm{a})$ & 6 & 2.8 & 0.12 \\
\hline$\left(\mathrm{g} \cdot \mathrm{MPa}^{-1} \cdot \mathrm{h}^{-1}\right)$ & $70 \pm 10(a)$ & $60 \pm 17(a)$ & 6 & 0.2 & 0.69 \\
\hline $\begin{array}{l}\text { Kshoot:LA } \\
\left(\mathrm{g} \cdot \mathrm{MPa}^{-1} \cdot \mathrm{h}^{-1} \cdot \mathrm{m}^{-2}\right)\end{array}$ & $115 \pm 24(b)$ & $20 \pm 5(a)$ & 6 & 15.6 & $<0.01$ \\
\hline Kroot: root DM & $67+12(a)$ & $182+47(b)$ & 6 & 55 & 004 \\
\hline$\left(\mathrm{g} \cdot \mathrm{MPa}^{-1} \cdot \mathrm{h}^{-1} \mathrm{~g}^{-1} \cdot \mathrm{dry}\right.$ mass $)$ & & & & & \\
\hline $\begin{array}{l}\text { Huber value } \cdot 10^{-3} \\
\qquad\left(\mathrm{~cm}^{2} \cdot \mathrm{cm}^{-2}\right)\end{array}$ & $1.6 \pm 0.6(b)$ & $0.3 \pm 0.1$ (a) & 6 & 25.0 & $<0.01$ \\
\hline
\end{tabular}

Light use traits

Total chlorophyll $\left(\mu \mathrm{g} \cdot \mathrm{cm}^{-2}\right)$

$20.7 \pm 2.8$ (a) $48.8 \pm 2.6$ (b) $10 \quad 54.3<0.01$

Total chlorophyll

$\left(\mathrm{mg} \cdot \mathrm{g}^{-1}\right)$

Chlorophyll a/b

$1.2 \pm 0.1$ (a) $\quad 6.0 \pm 0.4$ (b) $\quad 10 \quad 126.5<0.01$

AsatLA

$\left(\mu \mathrm{mol} \mathrm{CO}_{2} \mathrm{~m}^{-2} \mathrm{~s}^{-1}\right)$

$2.47 \pm 0.06$ (b) $2.08 \pm 0.07$ (a) $10 \quad 16.3<0.01$

$\operatorname{RLA}\left(\mu \mathrm{mol} \mathrm{CO} \mathrm{m}^{-2} \mathrm{~s}^{-1}\right) \quad 2.6 \pm 0.4(\mathrm{a}) \quad 2.2 \pm 0.4(\mathrm{a}) \quad 6 \quad 0.4 \quad 0.53$

$\begin{array}{llllll}\text { Light compensation point } & 13.2 \pm 2.5 \text { (a) } & 8.4 \pm 1.7 \text { (a) } & 6 & 2.6 & 0.14\end{array}$ $\left(\mu \mathrm{mol} \mathrm{m}{ }^{-2} \cdot \mathrm{s}^{-1}\right)$

AsatLDM

$\left(\mu \mathrm{mol} \mathrm{CO} \cdot \mathrm{g}^{-1} \mathrm{~s}^{-1}\right) \cdot 10^{-3}$

$\left(\mu \mathrm{mol} \mathrm{CO} \mathrm{g}^{-1} \mathrm{~s}^{-1}\right) \cdot 10^{-3}$

$10 \pm 3(a) \quad 66 \pm 6(b) \quad 6 \quad 34.3<0.01$

$12 \pm 3($ a) $\quad 27 \pm 10($ b) $\quad 6 \quad 5.2 \quad 0.04$

$\mathrm{Fv} / \mathrm{Fm}$

$0.47 \pm 0.03$ (a) $0.81 \pm 0.01$ (b) $10121.1<0.01$ 


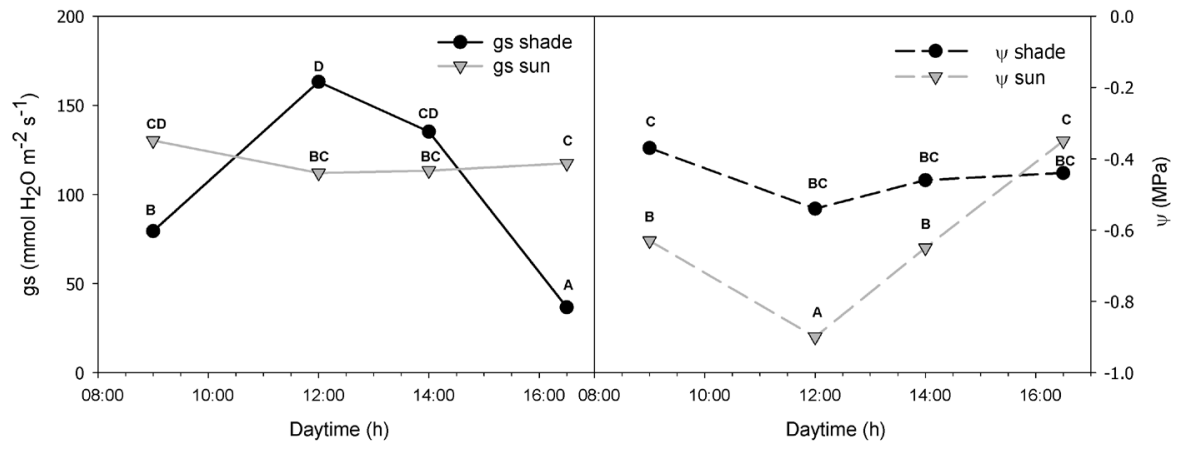

FIGURE I Stomatal conductance $(\mathrm{gs})\left(\mathrm{mmol} \mathrm{H} \mathrm{O} \mathrm{m}^{-2} \cdot \mathrm{s}^{-1}\right)$ and leaf water potential $(\Psi)(\mathrm{MPa})$ throughout the day of $C$.canjerana plants growing in an open area (sun) or under the dense rainforest canopy (shade) during the summer in the pot experiment. Different letters show significant differences along the day and between means of shade and sun $(p<0.05)$.

were considered dead and excluded from the analysis. Soil water content varied between $35 \%$ in the center of a gap and $51 \%$ under the close canopy, with a mean of $41 \%$ for all data. However, there were no significant differences in soil water content between positions (data not shown). There was a high correlation between PAR and soil and air temperatures, and negative correlation with air relative humidity. PAR was positively correlated with collar diameter, height, chlorophyll a/b ratio and ETR. PAR was negatively correlated with SLA and total chlorophyll concentrations, expressed in mass and area basis (Table 3 ).

When plants were divided in three classes considering the percentage of incident transmitted light in the position were it was planted, air relative humidity, soil and air temperatures were similar in all the ranges, but collar diameter, height, cholorophyll a:b and ETR were higher in the positions with higher incident light $(>40 \%)$ respect to the positions with lower incident light $(<15 \%)$ (Table 4$)$.

\section{DISCUSSION}

Plants acclimated to full sun and the dense forest coverage

In the rainforests, changes in coverage are associated with different light, water and temperature availability. C.canjerana plants modified their structure in response to the contrasting coverage, although it is classified as a tolerant species. Shade plants were taller and with thinner stems than sun plants (Table I). This is a typical response of non-tolerant or semi-tolerant species to optimize light interception in environments with sunflecks (Schall et al. 2012). Consistently, shade plants developed wider and thinner leaves than sun plants; these are morphological modifications that maximize light interception under the canopy with low carbon investment, as was observed in many shade semitolerant tree species (Shimizu et al. 2005) and in early succession species (Murphy et al. 2014). However, this response is not always observed in trees, as in the related species Cedrela fissilis (Vell.) that developed the same leaf area under sun or shade conditions (Campanello et al. 2008). Another morphological change observed at leaf level was the higher stomatal density and stomatal index (SI) in sun plants respect to shade plants (Table I). Higher

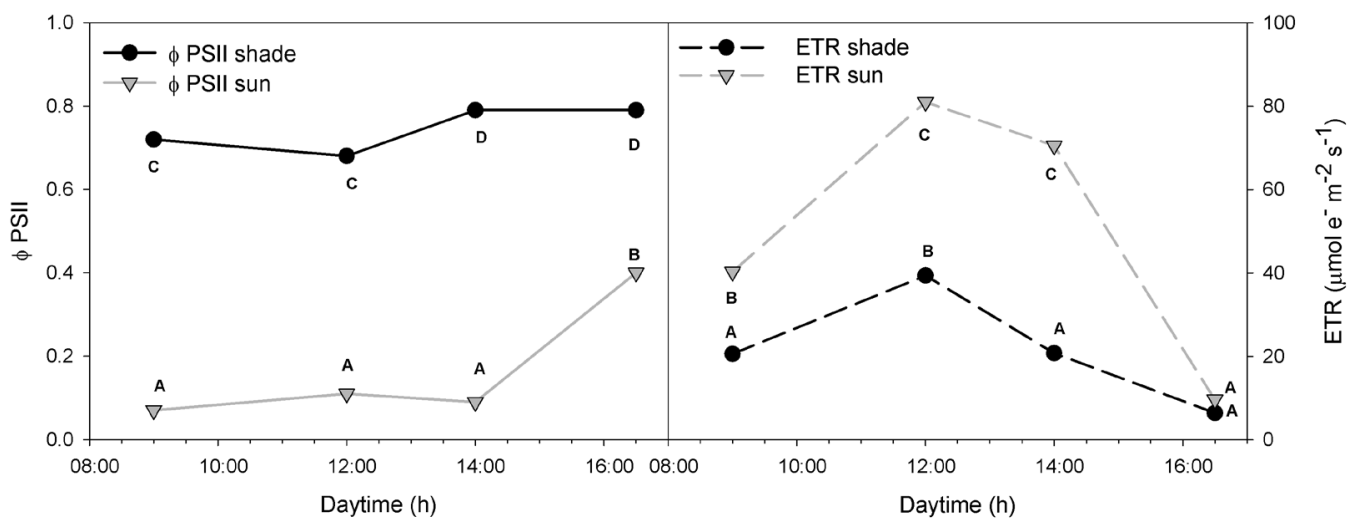

FIGURE 2 Photosystem II quantum yield ( $\varphi$ PSII) and electron transport rate (ETR) $\left(\mu \mathrm{mol}\right.$ e- $\left.\mathrm{m}^{-2} \cdot \mathrm{s}^{-1}\right)$ throughout the day in C.canjerana plants growing under full sun (sun) or under the dense rainforest canopy (shade) during the summer in the pot experiment. Different letters indicate significant differences along the day and between means of shade and sun $(p<0.05)$. 
TABLE 3 Media, median, standard error (SE), minimum (Min), maximum (Max) and replications (n) of the variables measured in C.canjerana plants growing in three gaps in the rainforest during 6 months and coefficient of correlation $(r)$ and probability (p) of each variable with PAR. Correlations include all the plants in the three gaps.

\begin{tabular}{|c|c|c|c|c|c|c|c|c|}
\hline Variable & Media & Median & SE & Min & Max & $\mathrm{n}$ & Correlation with PAR & \\
\hline Environmental traits & & & & & & & $r$ & $\mathrm{p}$ \\
\hline Midday PAR $\left(\mu \mathrm{mol} \mathrm{m} \mathrm{m}^{-2} \cdot \mathrm{s}^{-1}\right)$ & 275.59 & 72.00 & 36.87 & 3 & 1752 & 147 & & \\
\hline Transmitted light (\%) & 25.31 & 27.29 & 1.16 & 1.69 & 49.63 & 147 & 0.34 & $<0.01$ \\
\hline Air temperature $\left({ }^{\circ} \mathrm{C}\right)$ & 27.88 & 26.75 & 0.76 & 25.10 & 37.00 & 18 & 0.61 & $<0.01$ \\
\hline Soil temperature $\left({ }^{\circ} \mathrm{C}\right)$ & 22.92 & 22.20 & 0.44 & 21.10 & 27.90 & 18 & 0.64 & $<0.01$ \\
\hline Air relative humidity (\%) & 59.22 & 62.00 & 2.49 & 33.00 & 71.00 & 18 & -0.63 & $<0.01$ \\
\hline \multicolumn{9}{|l|}{ Plant traits } \\
\hline Collar diameter $(\mathrm{mm})$ & 5.62 & 5.49 & 0.11 & 2.45 & 9.53 & 147 & 0.24 & $<0.01$ \\
\hline Height $(\mathrm{cm})$ & 23.78 & 21.00 & 0.90 & 4.00 & 58.00 & 147 & 0.33 & $<0.01$ \\
\hline Leaflet area $\left(\mathrm{cm}^{2}\right)$ & 4.25 & 13.10 & 0.59 & 3.54 & 38.53 & 147 & 0.15 & 0.08 \\
\hline $\operatorname{SLA}\left(\mathrm{cm}^{2} \cdot \mathrm{g}^{-1}\right)$ & 319.14 & 303.88 & 7.09 & 133.39 & 589.09 & 147 & -0.18 & 0.04 \\
\hline Total Chl $\left(\mu \mathrm{g} \cdot \mathrm{cm}^{-2}\right)$ & 41.94 & 42.69 & 0.98 & 25.21 & 57.12 & 54 & -0.36 & 0.01 \\
\hline Total Chl $\left(\mathrm{mg} \cdot \mathrm{g}^{-1}\right)$ & 13.24 & 12.82 & 0.40 & 6.92 & 19.65 & 54 & -0.45 & $<0.01$ \\
\hline $\mathrm{Chl} a: \mathrm{b}^{\circ}$ & 2.10 & 2.08 & 0.03 & 1.67 & 2.67 & 54 & 0.35 & 0.01 \\
\hline $\mathrm{Fv} / \mathrm{Fm}$ & 0.87 & 0.88 & 0.01 & 0.61 & 0.91 & 54 & -0.24 & 0.07 \\
\hline $\operatorname{ETR}\left(\mu \mathrm{mol}\right.$ e- $\left.\mathrm{m}^{-2} \cdot \mathrm{s}^{-1}\right)$ & 38.18 & 20.36 & 3.91 & 0.96 & 286.59 & 147 & 0.64 & $<0.01$ \\
\hline $\mathrm{gs}\left(\mathrm{mmol} \mathrm{H} \mathrm{H}_{2} \mathrm{~m}^{-2} \cdot \mathrm{s}^{-1}\right)$ & 118.95 & 112.00 & 5.12 & 38.9 & 260.4 & 147 & $<0.01$ & 0.98 \\
\hline
\end{tabular}

$\mathrm{SI}$ in environments with higher radiation was observed in many species from other families (Camacho and Bellefleur 1996; Brodribb and Jordan 20I I; Nascimento et al. 20I5) and from the same family (Murphy et al. 20I2). It is important to remark that the increase in number of stomata per unit area was not only the effect of lower leaf expansion (i.e. smaller cell size or higher number of cell per unit area) but the proportion of stomata formed by each epidermal cell was also higher in sun than in shade plants. The increase in the number of stomata can be related with the need of more refrigeration in sun plants, due to the higher irradiance, lower air relative humidity and higher air temperature, and related with the higher capacity of leaves to conduct water in liquid phase $\left(\mathrm{K}_{\text {shoot }}: \mathrm{LA}\right)$ registered in sun plants respect to shade plants (Table 2).

Shade plants accumulated less dry mass in roots than sun plants (Table I). Reduction in root volume and in shoot:root ratio in response to low irradiance was observed in Fagus sylvatica (L.) (beech) and Picea abies (L.) Karst (Schall et al. 20I2). Higher root mass under sun can increase soil exploration and the delivery of water to the shoot. However, the partial stomatal closure and the drop in water potential at midday in sun plants (Figure I) reflect that the increase of root mass was not enough to counteracted water loss by transpiration. Therefore, sun and shade plants have very different morphology and size because they were subject to light and water stress, as will be analyzed in the following paragraphs.

Plants suffered water stress under the full sun

Plants adjusted in six months their hydraulic architecture during the growing season combining changes in different organs. By contrary, beech (Fagus sylvatica L.) saplings needed two years to acclimate their hydraulic architecture to the gap opening (Caquet et al. 2009). Hydraulic conductance is the capacity of the

TABLE 4 Environmental and physiological traits analyzed by three ranges of transmitted light whithin the gaps, in the gap experiment. If data were analyzed by ANOVA, F and p-value were reported. Some traits did not fit ANOVA assumptions and were analyzed with non-parametric test Kruskal Wallis $(\mathrm{KW})$ so $\mathrm{H}$ and $\mathrm{p}$-value are reported. For each variable, different letters indicate significant differences $(\mathrm{p}<0.05)$.

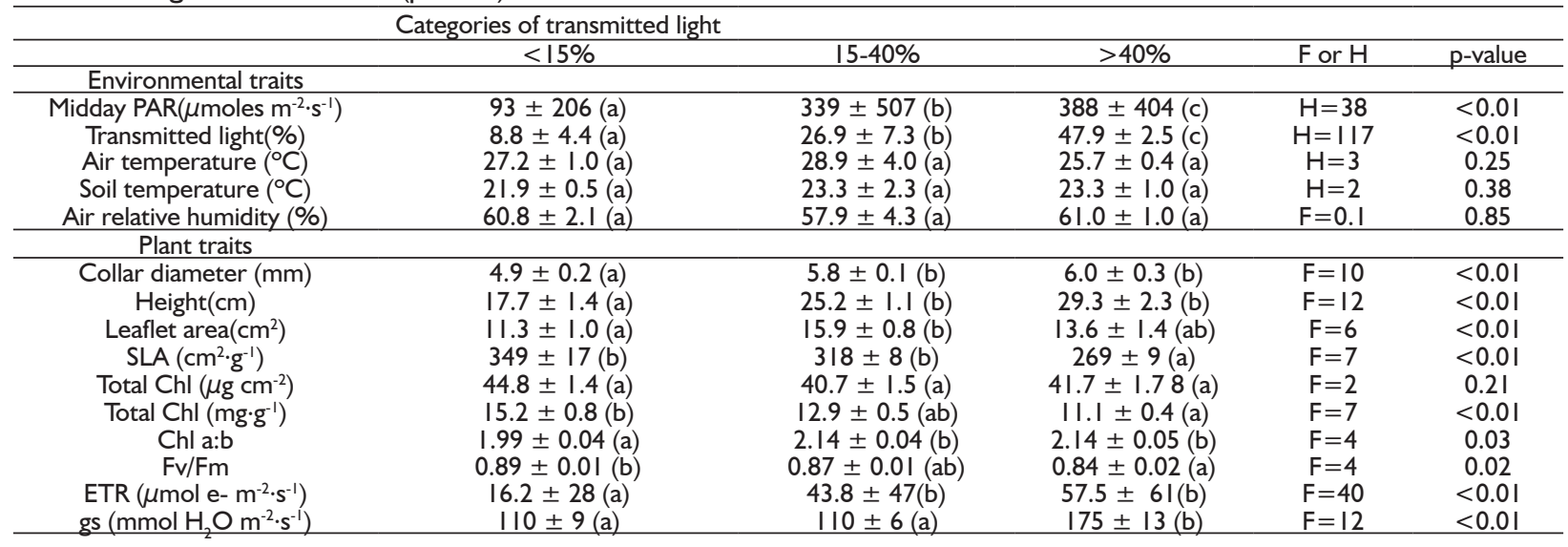


plant and each organ to conduct water in liquid phase. Conductances of the whole plant were similar in sun and shade plants (Table 2). However, conductances were different when scaled by leaf area or root dry mass (Table 2), i.e. the capacity of each unit area of leaf to conduct water was higher in sun plants while the capacity of each gram of root to conduct water was higher in shade plants. These results demonstrate that $C$.canjerana plants can develop changes in 6 months to adjust not only the morphology but also the functionality of the organs in response to the environment, to acquire the resource that was limiting growth. Sun plants increased shoot hydraulic conductance $\left(\mathrm{K}_{\text {shoot }}: \mathrm{LA}\right)$ (Table 2$)$ and $\mathrm{SI}$ in the sun condition (Table I), to maintain leaf hydration with the stomata open under high evapotranspirative demand (Figure I). This higher capacity to deliver water avoided the drop of leaf water potential to harmful values, as was observed even at midday (Figure I). Harmful water potentials are those that produce irreversible damage in the leaf tissues and defoliation, and no defoliation was observed in sun plants. The higher $\mathrm{K}_{\text {shoot }}$ :LA in sun plants was due to the reduction in leaf area, as was reflected in the 6-fold higher Huber value in sun plants respect to shade plants. Huber value reflects the capacity of a plant to adjust its dry mass partitioning between xylem and leaves to maintain homeostasis in leaf water relations (Carter and White 2009). Taken together all the changes in traits important to water use, it is evident that plants under full sun developed changes to minimize the negative impact of the higher evaporative demand and higher temperature, i.e. the open condition implies a moderate water stress for C.canjerana plants.

Plants under the dense canopy did not suffer water stress

Shade plants developed smaller roots (Table I) with higher hydraulic conductance $\left(\mathrm{K}_{\text {root }}\right.$ :total root DM) (Table 2). Five tropical trees had higher hydraulic conductance in roots when growing in the shade compared with plants under full sun (Shimizu et al. 2005). Therefore, shade plants can deliver enough water to the shoot with low carbon investment. Moreover, shade plants had the higher stomatal conductance at midday, with no decrease of leaf water potential (Figure I). The low hydraulic conductance per unit leaf area $\left(\mathrm{K}_{\text {shoot }}: \mathrm{LA}\right)$ (Table 2) and low stomatal index (SI) (Table I) of shade plants can explain why they can open the stomata at midday without compromising leaf hydration. The stomatal opening at midday is possiblly related with the higher light incident below the canopy at that daytime, so it is related with photosynthetic activity. Therefore, no signal of water deficit stress was observed in shade plants.

Sun plants suffered only moderate stress by excess of light

Sun plants possibly suffered some damage in the photosynthetic apparatus, reflected on the lower Fv/Fm respect to shade plants, which had the optimum value (Table 2). Fv/Fm represents the balance between the rate of photodamage and rate of PSII repair and this ratio is not related with changes in light absorption, for example due to changes in chlorophyll content or leaf water content (Kalaji et al. 20I4)methodology, and the hands on application of chlorophyll ( $\mathrm{Chl}$ as those observed in plants of each coverage condition (Table 2 ). However, the damage in sun plants was not severe and the global capacity of fixing carbon was higher in sun than in shade plants, as reflected by the higher ETR and dry mass accumulation of sun plants (Table I). Similarly, in three shade tolerant tropical trees a reduction in $\mathrm{Fv} /$ $\mathrm{Fm}$ in plants exposed to high radiation and a reduction in total chlorophyll concentration was observed, with any impact in growth, demonstrating that trees considered shade tolerant are able to acclimate to high radiation (Krause et al. 2012). The low chlorophyll concentration (Table 2) and thicker leaves (Table I) developed in sun plants could contribute to avoid damages by excess of light. Moreover, sun plants at midday used only $10 \%$ of the incident light along the day, as can be seen in the low $\varphi$ PSII (Figure. 2). As incident radiation under full sun was high, the ETR of sun plants was twice the ETR of shade plants, although the latter used more than $70 \%$ of the incident radiation. Higher capacity of fixing carbon in sun plants along the time is confirmed by the higher growth of sun plants respect to shade plants. Therefore, sun plants were exposed to moderate stress by high radiation but its anatomical and physiological changes avoided meaningful damages and reduction in growth.

Plants under the dense canopy suffered stress by deficit of light

Shade plants made changes to increase light interception (i.e. higher SLA, wider leaf area, more elongated stems) (Table I). Surprisingly, the curves of net carbon assimilation rate in response to light expressed in leaf area basis were similar in plants growing in both conditions (Table 2), i.e. respiration, light compensation point and photosynthetic rate were similar in plants growing under full sun or below a closed canopy. In tropical trees acclimatized to gaps with three levels of 
light, the curves of carbon assimilation rate in response to light were different between sites in three shade intolerant species, while there was no differences between curves in two shade tolerant species (Guzmán and Cordero 2013). However, in four shade tolerant species, photosynthetic light response curves were different in plants growing under close canopy, in a small gap or in a big gap (Kuehne et al. 2014)a moderately shade-tolerant tree species, is failing to regenerate throughout its native North American range, while successful recruitment in Central Europe has been observed since its introduction. To examine whether comparative photosynthetic performance could explain the regeneration success of this non-native species in Central Europe, we compared the physiological and morphological seedling traits of red oak with three co-occurring tree species under three canopy types in southwestern Germany. Native species included a moderately shade-tolerant native oak (Quercus robur L., following the expected pattern of acclimation to shade. C.canjerana plants have similar photosynthetic rate at high irradiance in sun and shade plants, possibly because shade plants can use high intensity sunflecks that reach the understory across the leaves (Smith and Berry 2013). However, if maximum net photosynthetic rate is expressed in leaf dry mass basis, shade plants had higher maximum photosynthetic rate, due to the higher chlorophyll concentration (Table 2) and SLA (Tablel). Net photosynthesis expressed in dry mass basis reflect the cost of building leaves, therefore shade plants can fix more carbon by each unit of dry mass invested in leaves. However, as the incident radiation is lower under the canopy than under full sun, the accumulated carbon fixation along time is lower in shade plants than in sun plants. The lower carbon fixation rate is corroborated by the lower ETR (Figure 2) and lower whole-plant dry mass accumulation (Table I) in shade plants respect to sun plants. Therefore, although shade plants developed more leaf area (Table I), with higher chlorophyll content and bigger antennas (i.e. lower chlorophyll a:b) and had high photosynthetic rate at high radiation (Table 2 ), the low incident radiation under the canopy limited dry mass accumulation. Therefore, the closed canopy imposed to C.canjerana plants a severe stress by low radiation (Lichtenthaler 1996), but no mortality was observed.

Light or water stress under different intensity of canopy coverage in the rainforest

Knowing the morphological and physiological acclimation can help to understand plant establishment in gaps. Plants growing in different positions in the gaps responded to light availability in growth and in physiological traits during the first growing season (Table 3 and 4). Height and collar diameter were positively correlated with PAR (Table 3), i.e. plants with higher availability of light grew more than plants with lower availability. In a tropical forest, shade tolerant as well as light-demanding species grew taller if transmitted light that reached the understory was higher (Chou et al. 2017), in sites with maximum transmitted light similar to our gaps. Therefore, canopy openness to certain level can favor even shade tolerant trees.

The positions with higher incident radiation within the gap (Table 4) are less stressful for C.canjerana plants than open areas. Interestingly, stomatal conductance (gs) at midday correlated positively with PAR (Table 3 ), although in the pot experiment gs at midday was higher in shade plants than in sun plants (Figure I). The differences between experiments could derive from the heterogeneity of light along the day the positions with higher incidence of sun radiation in the gaps, that received shade during the morning and the afternoon. On contrary, in the pot experiment, sun plants received full sun all along the day. Therefore, the exposure to the sun in the natural rainforest is never as high as in open areas. Consequently, some morphological and physiological traits were better in the plants in the positions with higher incident radiation within the gaps than in sun and shade plants. For example, Fv/Fm (which indicates light stress) is higher in plants in any position within the gap (Table 4) than in sun plants in the pot experiment (Table 2), so plants in the gaps did not suffer stress by excess of light. Photosynthetic rate (ETR) and gs were higher in the in the positions in the gaps with higher incident radiation than in those with medium and low incident radiation (Table 3 and 4), and even higher than in sun plants in the pot experiment (Figure I), indicating that plants in the gaps did not suffer water deficit stress at midday, as sun plants did. Consequently, the conditions with higher incident radiation within the gap are better for C.canjerana growth than positions with lower incident radiation. Therefore, in situations in which C.canjerana plants can naturally regenerate, plants can develop morphological and physiological changes to tolerate excess of light (for example lower chlorophyll content, reduction in leaf area, lower specific leaf area) and tolerate water stress (for example, higher leaf hydraulic conductance, higher Huber value, higher stomatal index, partial stomatal closure) that permit higher growth. Therefore, plants did not suffer severe water stress or stress by excess of light in any place of the gaps. On contrary, below the closed canopy, plants 
acclimate to low radiation by increasing total chlorophyll and chlorophyll b concentrations and increasing specific leaf area, although photosynthetic rate and water gas exchange were lower. However, below the dense canopy low radiation limited plant growth, so the stress by light limitation is severe, although plants can survive at least for six months. This information is important to manage this species in a forest restoration plan: after planting or detecting natural regeneration, it is necessary to reduce the shade produced by the understory to stimulate C.canjerana growth. The better condition to C.canjerana growth in the rainforest is in positions with high incidence of light. Although plantation in open areas is possible and plants survive without forest coverage, the stress by high temperature, high irradiance and low air humidity induce morphological and physiological changes to avoid severe stress, so growth is not optimal. It is noticeable the capacity of $C$.canjerana to change its morphology and physiology to acclimate to different microenvironments, and to reduce stress by excess of light and deficit of water. Therefore, it is a suitable species to be used in rainforest restoration, in areas where the canopy coverage changes in space and time. It would be interesting to perform pot experiments to evaluate other timber species with similar ecological requirements, to detect other species suitable to restoration plans.

\section{CONCLUSION}

Many of the functional traits that changed in response to canopy coverage were related with water use and others with light use. Under full sun, plants acclimated to water deficit stress and the stress by excess of light was mild. However, low light availability severally limited growth under the dense forest canopy. The capacity of C.canjerana to acclimate both to high and low canopy coverage makes it appropriated for enrichments programs in rainforests. The pot experiment with plants exposed to two extreme covering conditions (under closed canopy coverage and in full sun open area) was useful to know the capacity of the species to change morphological and physiological traits. These traits are compromised during the acclimation to different canopy coverage in the rainforest. It is important to remark that, in acclimation to shade or sun, traits related with water use are so or more important than traits related with light use.

\section{ACKNOWLEDGMENTS}

We thank the staff of Campo Anexo Manuel Belgrano (INTA EEA Montecarlo) in San Antonio, Misiones for helping in the experiment startups and for taking care of them.

\section{REFERENCES}

GARZÓN, M. B, ALÍA, R, ROBSON, T. M.; ZAVALA, M. A. Intra-specific variability and plasticity influence potential tree species distributions under climate change. Global Ecology and Biogeography, v. 20, p.766-778, 201 I.

BRODRIBB, T.J.; JORDAN, G. J. Water supply and demand remain balanced during leaf acclimation of Nothofagus cunninghamii trees. New Phytologist, v. 192, p.437-448, 201 I.

CAMACHO, M.; BELLEFLEUR, P. Aclimatación morfológica a la luz en seis especies arbóreas de los bosques montanos de Costa Rica. Revista de Biología Tropical, v.44, p.7I-79, 1996.

CAMPANELLO, P.I., GATTI, M.G.; GOLDSTEIN, G. Coordination between water-transport efficiency and photosynthetic capacity in canopy tree species at different growth irradiances. Tree Physiol, v.28, p.85-94, 2008.

CAQUET, B.; BARIGAH, T.S.; COCHARD, H. et al Hydraulic properties of naturally regenerated beech saplings respond to canopy opening. Tree Physiol, v. 29, p. |395-|405, 2009.

CARGNELUTTI FILHO, A.; ARAUJO, M.M.; GASPARIN, E.; AVILA, A.L. Dimensionamento amostral para avaliação de altura e diâmetro de mudas de Cabralea canjerana. Ciência Rural, v.42, p.|204-121 I, 2012.

AIMI S. C.; ARAUJO, M. M., LEÓN, E. B., et al Volumen de contenedores y dosis de fertilizante de liberación controlada en el crecimiento de plantas de Cabralea canjerana producidas en vivero. Bosque (Valdivia), v. 37 , p.:40I-407., 2016.

CARTER, J.L.; WHITE, D.A. Plasticity in the Huber value contributes to homeostasis in leaf water relations of a mallee Eucalypt with variation to groundwater depth. Tree Physiol, v.29, p.|407-I4I8, 2009

CHOU, C.B.; HEDIN, L.O.; PACALA, S.W. Functional groups, species and light interact with nutrient limitation during tropical rainforest sapling bottleneck. Journal of Ecology, v.106, p.157-167, 2018.

DI RIENZO, J.A; CASANOVES, F; BALZARINI, M.G. et al InfoStat, 2015

FELTON, A.; FELTON, A.M.; WOOD, J.; LINDENMAYER, $D . B$. Vegetation structure, phenology, and regeneration in the natural and anthropogenic tree-fall gaps of a reducedimpact logged subtropical Bolivian forest. For Ecol Manage, v.235, p.186-193, 2006.

FRAZER, .G.W.; CANHAM, C.D.; LERTZMAN, K. Gap Light Analyzer (GLA): Imaging software to extract canopy structure and gap light transmission indices from truecolour fisheye photographs, users manual and program documentation, 1999.

GÁLHIDY, L.; MIHÓK, B.; HAGYÓ, A., et al Effects of gap size and associated changes in light and soil moisture on the understorey vegetation of a Hungarian beech forest. Plant Ecology, v. I83, p.I33-145, 2006. 
GUZMÁN, J.A.Q.; CORDERO, R. R. A. S. Growth and photosynthetic performance of five tree seedlings species in response to natural light regimes from the Central Pacific of Costa Rica. Revista de Biología Tropical, v.6I, p. I4331444, 2013.

HAWORTH, M.; ELLIOTT-KINGSTON, C.; MCELWAIN, J.C. The stomatal $\mathrm{CO} 2$ proxy does not saturate at high atmospheric $\mathrm{CO}_{2}$ concentrations: Evidence from stomatal index responses of Araucariaceae conifers. Oecologia, v. I67, p.|I-19, 201।

INSKEEP, W.P.; BLOOM, P.R. Extinction Coefficients of Chlorophyll a and b in N,N-Dimethylformamide and $80 \%$ Acetone. Plant Physiol, v.77, p.:483-485, 1985.

KALAJI, H.M.; SCHANSKER, G.; LADLE, R.J. et al Frequently asked questions about in vivo chlorophyll fluorescence: Practical issues. Photosynthesis Research, v.122, n. 121 I58, 2014.

KRAUSE, G.H.; WINTER, K.; MATSUBARA, S. et al Photosynthesis, photoprotection, and growth of shadetolerant tropical tree seedlings under full sunlight. Photosynthesis Research, v. I I3, p.273-285, 2012.

KUEHNE, C.; NOSKO, P.; HORWATH, T.; BAUHUS, J. A comparative study of physiological and morphological seedling traits associated with shade tolerance in introduced red oak (Quercus rubra) and native hardwood tree species in southwestern Germany. Tree Physiol, v. 34, p. I84-93, 2014

LAMBERS, H.; CHAPIN III, F.S.; PONS, Y.L. Plant physiological ecology. Springer-Verlag, New York, 20I4, 605p.

LARCHER, W. Physiological Plant Ecology. Ecophysiology and stress physiology of functional groups, 4th edn. Springer, Berlin, 2003

LICHTENTHALER, H. K. Vegetation Stress: an Introduction to the Stress Concept in Plants. Journal of Plant Physiology, v. I48, p.4-14, 1996.

MELCHER, P.j.;, HOLBROOK, N.M.; BURNS, M.J. et al (20I2) Measurements of stem xylem hydraulic conductivity in the laboratory and field. Methods in Ecology and Evolution, v.3, p.685-694, 2012.
MONTAGNINI, F; JORDAN, C.F. Tropical Forest Ecology. The Basis of Conservation and Management, Ist Ed. Springer Berlin Heidelberg, 2005, 295p.

MURPHY, M.R.C.; JORDAN, G.J.; BRODRIBB, T.J. Acclimation to humidity modifies the link between leaf size and the density of veins and stomata. Plant Cell Environment, v.37, p.|24-131, 2014

MURPHY, M.R.C; JORDAN, G.J.; BRODRIBB, T.J. Differential leaf expansion can enable hydraulic acclimation to sun and shade. Plant Cell Environment, v. 35, p.|407-1418.

NASCIMENTO, C.K.; PASTORINI, L.H.;ROMAGNOLO, M. B., SOUZA, L.A. Do Eugenia hiemalis seedling leaves under different light conditions develop phenotypic plasticity? Plant Ecology, v. 216, p. I57I-I58I, 2015.

NIINEMETS, $U$. Responses of forest trees to single and multiple environmental stresses from seedlings to mature plants: Past stress history, stress interactions, tolerance and acclimation. Forest Ecology and Management, v. 260, p.1623-1639, 2010.

RODRÍGUEZ-GAMIR, J.; PRIMO-MILLO, E.; FORNER-GINER, M.Á. An integrated view of whole-tree hydraulic architecture. Does stomatal or hydraulic conductance determine whole tree transpiration? PLoS One, v.II, p.I-19, 2016

SCHALL, P.; LÖDIGE, C.; BECK, M.; AMMER, C. Biomass allocation to roots and shoots is more sensitive to shade and drought in European beech than in Norway spruce seedlings. Forest Ecology and Management, v.266, p.246-253, 2012

SHIMIZU, M.; ISHIDA, A.; HOGETSU, T. Root hydraulic conductivity and whole-plant water balance in tropical saplings following a shade-to-sun transfer. Oecologia, v. 143, p. 189-197, 2005.

SMITH, W.K.; BERRY, Z.C. Sunflecks? Tree Physiol, v. 33, p.233-237, 2013. 